\title{
CONTRIBUTION OF ACADEMICIAN MAKSYM PALAMARCHUK TO THE RESEARCH OF AGRO-INDUSTRIAL COMPLEX OF UKRAINE FROM A PRESENT-DAY PERSPECTIVE
}

\author{
Valentyna NAGIRNA \\ Institute of Geography, National Academy of Sciences of Ukraine, Kyiv \\ vnagirnyy40@mail.ua
}

\begin{abstract}
The paper enlightens the scientific achievements of Maksym Palamarchuk, an outstanding Ukrainian scientist, geographer, academician of the National Academy of Sciences of Ukraine, in the field of agro-industrial researches in Ukraine. The 100th anniversary of his birth was celebrated on 22 October 2016. Maksym Palamarchuk made a great contribution to scientific theory explaining formation of agro-industrial complexes (AICs) in agriculture, including their classification and determination of development patterns. In fact, prominent scientist laid methodological foundations for the study of AIC. His fundamental developments include system-structural analysis of specialized AICs in branch, functional and territorial aspects, as well as development of conception for reformation of regional AICs in transition to the market economy. The scientist rationalized the priorities for development of agriculture in independent Ukraine, outlined the main directions of improving its structure and territorial organization of production. In particular, he stressed the need for sustainable use of land resources, restoration of soil fertility, improving the competitiveness of agricultural products on the world markets. Scientific works, written by Maksym Palamarchuk, remain relevant for the modern development of AICs in Ukraine.
\end{abstract}

Key words: agro-industrial complex, patterns of formation, branch structure, functional structure, territorial structure, rational land management, directions of development of AIC in Ukraine.

DOI: https://doi.org/10.17721/2413-7154/2016.76.48-53

UDC: 911.3

\section{ВНЕСОК АКАДЕМІКА М.М. ПАЛАМАРЧУКА У ДОСЛІДЖЕННЯ АГРОПРОМИСЛОВОГО КОМПЛЕКСУ УКРАЇНИ В КОНТЕКСТІ СУЧАСНИХ РЕАЛІЙ}

\author{
Валентина НАГІРНА \\ Iнститут географії НАН України, м. Київ \\ vnagirnyy40@mail.ua
}

\begin{abstract}
Анотація: Публікація висвітлює науковий доробок видатного українського вченого-географа, академіка НАН України М. М. Паламарчука, 100-річчя від дня народження якого минуло 22 жовтня 2016 року, в галузі дослідження агропромислового комплексу (АПК) України. У статті показано великий вклад вченого в теорію формування АПК, визначення закономірностей його розвитку, розроблення методичних основ дослідження і типізацію АПК. До фундаментальних розробок відносяться системно-структурний аналіз спеціалізованих АПК в галузевому, функціональному й територіальному аспектах, розроблення концепції реформування регіональних АПК за умов переходу до ринкової економіки. Вчений обґрунтував пріоритетність розвитку АПК в економіці незалежної України, визначив основні напрями його розвитку, вдосконалення структури і територіальної організації виробництва. Особливо наголошувалося на необхідності раціонального використання земельних ресурсів, відновлення родючості ґрунтів, підвищенні конкурентоспроможності продукції АПК на світових ринках. Показано актуальність напрацювань акад. М.М. Паламарчука в умовах сучасного розвитку АПК України.

Ключові слова: агропромисловий комплекс (АПК), закономірності формування, галузева, функціональна й територіальна структура АПК, раціональне землегосподарювання, напрями розвитку АПК України.
\end{abstract}

DOI: https://doi.org/10.17721/2413-7154/2016.76.48-53

УдК: 911.3

Зміст багатогранної наукової спадщини академіка М.М.Паламарчука в галузі агропромислового комплексу (АПК) визначений потребами господарської діяльності, сприятливими умовами землегосподарювання в Україні, необхідністю вдосконалення управління й територіальної організації аграрної сфери, збереження природно-ресурсного потенціалу й охорони земельних ресурсів. Спектр його наукових досліджень був доволі широким - від теоретичних

(C) В. Нагірна

основ агропромислового комплексоутворення, сутності й закономірностей формування територіальних АПК, їх структурного аналізу до детального вивчення агропромислового комплексу України, включаючи спеціалізовані й регіональні АПК. Будучи фахівцем високого рівня, досконало володіючи методологією та методами досліджень, грунтуючись на теорії геокомплексології, він розкрив фундаментальні властивості та процеси комплексоутворення в аграрній сфері, їх зумовленість природними умовами й економічними детермінантами. Трактуючи АПК як специфічне 
виробничо-територіальне утворення, системний об'єкт, де взаємодіють різні види господарської діяльності, акцентуючи на узгодженні природних, соціальних і економічних процесів, забезпеченні умов для розвитку сільської місцевості, акад. М.М.Паламарчук створив українську школу суспільно-географічних досліджень АПК. Ним вихована ціла плеяда науковців, які успішно захистили свої кандидатські чи докторські дисертації 3 аграрної тематики. Серед них д.г.н. Г. В. Балабанов, к.г.н. Л. П. Ковтун, к.г.н. О.Д. Краєвий, к.г.н. С.М. Малюк, д.г.н. В.П. Нагірна, д.г.н. Я.Б. Олійник, к.г.н. І.М. Пушкар, д.е.н. В.Ф. Семенов, к.Г.н. В.Г. Щабельська та інші.

Під керівництвом М.М. Паламарчука в Інституті географії НАН України були виконані важливі наукові дослідження 3 проблеми формування i територіальної організації АПК, особливостей його розвитку в Україні. В узагальненій формі результати досліджень висвітлено у монографіях «Свеклосахарное производство Украинской ССР» (1964), «Территориальная организация агропромышленных комплексов» (1985), «Економічна i соціальна географія України 3 основами теорії» (1998), а також у багатьох статтях у наукових журналах, енциклопедичних виданнях, матеріалах наукових форумів.

Розробляючи основні стратегічні напрями формування структури суспільно-територіального комплексу незалежної України, М. М. Паламарчук одним із перших серед вітчизняних географів визначив пріоритетний розвиток АПК в економіці країни, найважливішою основою для їі виживання як незалежної держави. Для цього в Україні, наголошував учений, є всі передумови: українські чорноземи і сприятливі в цілому кліматичні умови, науково-технічний потенціал у галузях АПК, трудові традиції і любов українського народу до хліборобської праці. При цьому важливим $€$ обгрунтування структури агропромислового комплексу, налагодження виробництва машин, засобів захисту рослин, створення сучасної переробної промисловості. Слід домогтися раціональної структури посівних площ і ефективного використання землі. Треба досягти таких масштабів виробництва, щоб Україна перетворилася на одну 3 найбільших баз продовольства міжнародного значення [3]. Всі ці положення є ключовими й нині, вони мають бути покладені в основу стратегії розвитку АПК в сучасній Україні.

Особливого значення в розвитку агропромислового комплексу М. М. Паламарчук надавав сприятливому географічному розміщенню України, її участі у світових продовольчих ринках. Основою експорту мають бути розвиток таких спеціалізованих комплексів, як цукропромисловий, олійно-жировий, плодоовочепромисловий, льонарський. Вихід з економічної кризи, розвиток усієї економіки, добробут населення він пов'язував 3 якнайшвидшим розв'язанням проблем сільського господарства, сільського життя, інтенсифікації всіх ланок АПК.
3 іменем академіка М. М. Паламарчука пов'язане розроблення теоретичних основ агропромислового комплексоутворення. Ним було визначено суть, чинники і закономірності формування АПК із суспільно-географічних позицій. Під АПК автор розумів поєднання окремих ланок народного господарства, діяльність яких пов'язана з виробництвом, переробленням і збутом сільськогосподарської продукції. Головна його увага була звернена на агропромислові територіальні комплекси (АПТК). Це, за твердженням ученого, сукупність підприємств та організацій 3 виробництва, промислового перероблення, зберігання i реалізації сільськогосподарської продукції на певній території. До чинників формування АПТК відносяться: рівень економічного розвитку території i форми організації виробництва; природні умови i структура земельного фонду; науковотехнічний прогрес; народногосподарські потреби у продукції АПК країни загалом і регіону зокрема; забезпеченість трудовими ресурсами; транспортні умови [4].

На основі багатоаспектних досліджень і системно-структурного аналізу конкретних агропромислових комплексів, чинників ix формування М.M. Паламарчуком було виявлено закономірності агропромислового комплексоутворення і його особливості в Україні: 1) перетворення виробництва сільськогосподарської продукції та обслуговуючих його галузей у цілісну систему в масштабі районів, областей і всієї країни; 2) формування спеціалізованих АПК в результаті територіальної концентрації виробництва конкретних видів сільськогосподарської продукції та їі перероблення в районах 3 найбільш сприятливими природними і економічними умовами; 3) зосередження виробництва певних видів сільськогосподарської продукції та її перероблення в місцях територіальної концентрації населення [3].

Дія кожної з цих закономірностей визначається конкретними умовами території. Залежно від наявності й переважання тих чи інших чинників формування АПТК (великих систем розселення, винятково сприятливих природних умов, транспортної інфраструктури) домінуючими $\epsilon$ тільки певні закономірності. В АПТК регіонального масштабу сформувалася мережа організацій та підприємств не лише 3 виробництва сільськогосподарської продукції, а й постачання матеріальних ресурсів, ремонту та обслуговування техніки, внесення добрив, проведення меліоративних робіт, транспортування, зберігання і перероблення продукції, будівництва тощо.

Особливо важливим 3 позицій АПК i раціонального природокористування є виокремлення М. М. Паламарчуком спеціалізованих комплексів. На їх формування значно впливають зональність природних умов, родючість грунтів, традиційні навики населення. Виробництво окремих видів продукції (цукрові буряки, виноград, соняшник, 
кукурудза на зерно, льон-довгунець та інші) доцільно виробляти лише у певних регіонах. Завдяки особливо сприятливим природним і економічним умовам досягається висока економічна ефективність і створюються можливості для значного підвищення рівня територіальної концентрації виробництва сільськогосподарської сировини. Це є важливою передумовою для формування потужних переробних підприємств, створення системи обслуговуючих, допоміжних виробництв, закладів науки, розвитку підприємництва та агробізнесу.

Важливе місце в теорії АПК, розробленій акад. М. М. Паламарчуком, займає дослідження ïx структури [5]. Ним виділено галузеву, функціональну, територіальну й організаційну структуру АПК. Галузева структура відображує поєднання галузей, виробництв, інших видів діяльності, що функціонують взаємопов'язано і спрямовані на виробництво аграрної продукції. Сюди входять сільськогосподарське виробництво (рослинництво і тваринництво) та галузі, що забезпечують виробничо-технічне, іригаційномеліоративне та ветеринарно-санітарне обслуговування сільського господарства; галузі промисловості, що забезпечують сільське господарство й переробну промисловість необхідними засобами виробництва (сільськоосподарське машинобудування, машинобудування для тваринництва i кормовиробництва, виробництва мінеральних добрив та хімічних засобів захисту рослин, мікробіологічна та комбікормова промисловість, а також виробництва, що забезпечують заготівлю, транспортування, зберігання і реалізацію сільськогосподарської продукції). Вчений особливо наголошував на важливості поглиблення спеціалізації у сільському господарстві, підвищення товарності тих галузей, що виробляють сировину для переробної промисловості, розміщення ㄲï підприємств безпосередньо в місцях виробництва сировини. Важливим $є$ також узгодження сільського господарства і переробної промисловості 3 виробництвом засобів виробництва i предметів праці для них.

Ці, здавалося б загальновідомі речі, нині $\epsilon$ особливо актуальними для розвитку АПК України, її позиціювання у світі як аграрної країни. Засилля агрохолдингів, експортне спрямування виробництва сільськогосподарської продукції у вигляді сировини, істотне зменшення промислового перероблення вирощеної продукції (зерна, цукрових буряків, льону, сої) суттєво знижують ефективність АПК, його бюджетоформуючу функцію, зменшують роль України як потужного світового виробника продовольства. В галузевій структурі АПК значно знизилося, а подекуди зруйновано машинобудування для потреб сільського господарства, виробництво хімічних засобів захисту рослин, продукції з обслуговування переробної і харчової промисловості.

Функціональна структура, за визначенням M.M. Паламарчука, це наявність взаємозв'язаних міжгалузевих поєднань, співвідношення груп виробництв, що виконують певні комплексоутворюючі функції. Основними елементами функціональної структури АПК є агропромислові цикли виробництв. Вони формуються як послідовні стадії процесу перетворення вихідної сільськогосподарської сировини -. зерна, цукрових буряків, овочів, фруктів, насіння соняшника, а також молока, м'яса в кінцеву продукцію. Найпоширенішими в Україні є цукробуряковий, плодоовочеконсервний, олійно-жировий, картопляно-крохмале-спиртовий, молоко-промисловий, м'ясопромисловий цикли. В них поєднуються виробництва певного виду сировини, промислові підприємства, що ii переробляють, допоміжні та обслуговуючі виробництва (виробництво машин і устаткування, тари, мінеральних добрив, ремонтні підприємства, енергетична база). Виникають також супутні виробництва, що базуються на використанні відходів (підприємства 3 виробництва кормів, білково-вітамінних сумішей тощо).

Розроблення теорії функціональної структури АПК, виявлення основних стадій виробничого процесу, їх ролі в ефективності розвитку аграрної сфери, раціонального використання продукції сільського господарства є важливими для вдосконалення технології виробництва i перероблення сільськогосподарської сировини, впровадження інновацій, вдосконалення управління АПК.

Територіальна структура АПК відображає його внутрішню територіальну будову, особливості зосередження виробництва i промислового перероблення сільськогосподарської сировини, різні форми виробничих поєднань. Автор виділив регіональні та ареальні елементи територіальної структури. Ареальні елементи відбивають зональність природних умов, рівень концентрації і ефективність виробництва певних видів сільськогосподарської сировини. До ареальних елементів відносяться агропромислова зона, агропромисловий район, спеціалізована агропромислова зона, спеціалізований агропромисловий район. В низових (елементарних) комплексах поєднуються переробні підприємства 3 їх сировинними зонами.

М.М. Паламарчук виділив також організаційну структуру АПК, в основу якої було покладено форми і рівень усуспільнення виробництва. Вона, вважав автор, повинна бути основою для створення системи управління агропромисловим комплексом. Незважаючи на зміни, що відбулися в економічній системі в Україні, зокрема формах власності, напрямах землегосподарювання, це питання $\epsilon$ актуальним і нині. В умовах ринку сформувалися нові виробничі структури - високотоварні сільськогосподарські підприємства (агрохолдинги), фермерські господарства, сільськогосподарські кооперативи й господарства населення. Однак не було створено умов i дієвих механізмів для ефективного екологічно безпечного розвитку АПК 
і зокрема сільського господарства, вдосконалення його територіального управління. В аграрному секторі постали нові проблеми, пов'язані 3 деформацією його організаційно-виробничої структури, засиллям агрохолдингів, витісненням фермерських господарств.

Теорія структурного аналізу АПК, розроблена M.M. Паламарчуком, отримала широке визнання в наукових дослідженнях, підготовці фахівців 3 цієї тематики, була покладена в основу методики вивчення агропромислового комплексу України та і1і регіонів. Разом зі своїми учнями вчений опублікував впродовж 1960 - 1990-х років понад 70 наукових праць 3 питань розвитку АПК, сільського господарства, переробної промисловості, типології територіальних АПК, реформування аграрної сфери в умовах переходу до ринкових відносин. До речі, докторська дисертація М. М. Паламарчука, захищена ним у 1959 році, також була присвячена аграрній тематиці - дослідженню цукробурякового комплексу України, вдосконаленню його територіальної організації. За матеріалами дисертаційного дослідження опубліковано монографію «Свеклосахарное производство Украинской ССР» [2].

Особливо грунтовними 3 використанням системно-структурного аналізу були дослідження рослинницько-промислових i тваринницькопромислових спеціалізованих комплексів. Сюди ввійшли такі важливі питання, як виробничогалузева структура комплексу, включаючи виробництво продукції сільського господарства i ㄲi промислове перероблення, обслуговуючі підприємства (виробництво й ремонт сільськогосподарських машин, технологічного устаткування для переробної промисловості, тари та інше), транспортування та реалізація готової продукції. Значна увага була приділена територіальній організації АПК i зокрема сільськогосподарської ланки, ㄲï відповідності природно-географічним умовам України. Особливо докладно в розрізі підгалузей і основних виробників було розглянуто промислове перероблення сільськогосподарської сировини, сферу реалізації готової продукції, формування внутрішнього ринку. Важливу роль в процесі аналізу спеціалізованих АПК вчений приділяв розвитку науки, зокрема в галузях селекції та насінництва, впровадженню нової техніки та нових технологій у сферу перероблення сільськогосподарської сировини, покращенню асортименту та споживчих якостей готової продукції.

На основі використання масиву статистичних даних, інформаційно-аналітичних, законодавчих i нормативних матеріалів, а також численних наукових публікацій було зроблено грунтовний аналіз головних спеціалізованих АПК України, що давало змогу не тільки визначити їх роль в економіці країни, а й як вагомого конкурента у світовому виробництві. Це такі АПК, як зернопромисловий, цукропромисловий, плодоовочеконсервний, виноградо-виноробний,

льонопромисловий та інші. Серед тваринницьких АПК виділено м'ясопромисловий, молочнопромисловий і птахопромисловий спеціалізовані комплекси.

В результаті дослідження АПК України було визначено основні напрями їх розвитку: 1) припинення спаду i збільшення обсягів виробництва сільськогосподарської продукції (зерна, цукрових буряків, олійних культур тощо) за рахунок підвищення економічної ефективності виробництва i якості продукції; 2) вдосконалення спеціалізації виробництва, структури посівних площ сільськогосподарських культур відповідно до природно-географічних умов, структури земельного фонду різних регіонів, родючості грунтів; 3) вдосконалення технології виробництва, прискорення впровадження нових урожайних сортів сільськогосподарських культур, використання високоякісних посівних матеріалів; 4) підвищення рівня промислового перероблення сільськогосподарської сировини, модернізація підприємств, застосування прогресивних технологій; 5) вдосконалення територіальної структури АПК, розміщення i локального поєднання сільськогосподарських, заготівельних, промислових підприємств, наукових закладів тощо; 6) організація ринку зерна, як внутрішнього, так i зовнішнього, реформування системи заготівель шляхом лібералізації цінового механізму; 7) підвищення конкурентоспроможності виробництва сільськогосподарської сировини і продукції ¥ї промислового перероблення [3].

Академіком M. M. Паламарчуком було розроблено концепцію реформування регіонального АПК за умов переходу до ринкових відносин. Характерним для розвитку аграрної сфери того періоду були такі явища, як загроза монополізму, загальний дефіцит продукції, відсутність ринкової інфраструктури та кваліфікованих кадрів, масовий імпорт продовольства. За таких обставин вчений вважав за необхідне посилення державного регулювання аграрної сфери. Найважливішими принципами регулювання було визначено: аграрний протекціонізм, поєднання економічної і соціальної мети, індикативності й директивності, програмності й системності дій.

Прийняті нині в Україні закони щодо розвитку аграрної сфери і зокрема децентралізації управління, за якими передбачається розширення функцій i повноважень місцевих органів влади, підвищення їх відповідальності (а це особливо стосується розвитку аграрної сфери, землегосподарювання), підтверджують суголосність наукових положень акад. М. М. Паламарчука з сучасними реаліями. Держава, вважав учений, має формувати i вдосконалювати правове підгрунтя ринкових перетворень, здійснювати інвестиційну, фінансову i кредитну політику у сфері сільського господарства й АПК, формувати державні продовольчі резерви, здійснювати стимулюючий вплив на суб'єктів господарювання, регулювати засоби їх відносин 3 державою, захищати внутрішній ринок від 
негативного впливу іноземної конкуренції. Автор виділив основні напрями стратегії державного регулювання регіональних АПК в умовах переходу до ринку: 1) територіальний розподіл вигідних для виробника державних контрактів на постачання продукції; 2) дії, спрямовані на прискорення розвитку сільських регіонів; 3) виділення спеціалізованих районів експортної орієнтації. В умовах кризи, зазначено в його працях, важливими є пріоритетність виробництва засобів виробництва, розвитку переробної промисловості, системи заготівель продукції, фінансування регіональних державних програм, пільгове кредитування суб'єктів господарювання, економічне стимулювання виробництва найважливіших видів сільськогосподарської продукції, розвиток соціальної і виробничої інфраструктури.

Нині, коли в аграрній сфері України відбулися істотні зміни, що спричинили зменшення виробництва сільськогосподарської продукції, зниження його конкурентоспроможності на світових ринках, загострення екологічних проблем тощо, значення наукової спадщини М.М. Паламарчука щодо розвитку АПК зростає. Ця роль посилюється у зв'язку 3 необхідністю виходу країни $з$ системної кризи, де аграрна сфера, маючи значний природно-ресурсний потенціал, може стати, за висловом вченого, найважливішою основою виживання України. Існуюча система господарювання, посилення ролі агрохолдингів у виробництві сільськогосподарської продукції спрямовані на поглиблення грунтовиснажливого напряму землеробства, збільшення експорту сільськогосподарської сировини, а не продукції переробної промисловості, отримання надприбутків на користь агрохолдингів значно знижують роль АПК в економіці України. Зміна структури і спеціалізації сільського господарства, нехтування природно-географічними умовами розвитку галузі, відсутність сівозмін, занепад тваринництва призвели до істотного погіршення екологічної ситуації. Це виявляється в подальшій деградації земель, зниженні родючості грунтів, зменшенні продуктивності сільськогосподарських угідь. Економічна ефективність аграрної сфери дедалі більше залежить від екостану земельних ре6сурсів, раціональної спеціалізації сільського господарства [1].

На тлі соціальних трансформацій, що відбуваються в аграрному секторі, складною є ситуація у сільській місцевості, наближаючись у багатьох районах до кризової. Для переважної більшості сільських мешканців основною сферою прикладання праці і засобом виживання $\epsilon$ особисте господарство. Триває зменшення чисельності сільського населення, скорочення поселенської мережі, міграційне відтікання сільських мешканців.

Для вирішення сучасних проблем розвитку АПК, його позиціонування як стратегічного напряму розвитку економіки України важливим $\epsilon$ використання напрацювань академіка
M.M. Паламарчука у цій галузі. Найголовніші 3 них:

- Для ефективного розвитку АПК і зокрема сільського господарства, визначення напрямів його спеціалізації слід виходити 3 оцінки природних, суспільно-географічних i економічних умов розвитку аграрної сфери, кон'юнктури зовнішніх ринків;

- Істотним $є$ вдосконалення законодавчих та правових норм щодо системи землегосподарювання i розвитку сільської місцевості 3 урахуванням економічних, соціальних, екологічних та екістичних складових;

- Аграрна політика держави має бути спрямована на удосконалення земельних відносин, поширення різних форм господарювання, становлення багатоукладної економіки, підтримку фермерства;

- Підвищення територіальної концентрації виробництва сільськогосподарської сировини, формування спеціалізованих АПК мають відбуватися в районах 3 найбільш сприятливими природними умовами;

- Реформування АПК повинно здійснюватися комплексно, включаючи всі сфери й ланки: сільське господарство, переробну промисловість, виробництво засобів виробництва, агротехсервіс, заготівлі, зберігання та реалізацію продукції;

- Важливими є узгодженість між виробництвом сільськогосподарської сировини і розвитком переробної промисловості, поєднання інтересів виробників сировини та ㄲï переробників; вдосконалення структури i техніко-технологічне оновлення галузей переробної промисловості. Переробні підприємства мають стимулювати усі форми господарювання на селі;

$$
\text { Підвищення ефективності }
$$

конкурентоспроможності АПК слід пов'язувати 3 проведенням комплексу землеохоронних заходів, відновленням родючості грунтів, запровадженням науково обгрунтованих систем землеробства й новітніх технологій ресурсозбереження;

- Розвиток АПК має бути спрямований на розв'язання завдань соціального й економічного піднесення сільської місцевості, підвищення престижності сільської праці, розвиток агробізнесу на селі, формування ринкової інфраструктури.

Значення праць акад. М. М. Паламарчука нині особливо посилюється у зв'язку з необхідністю вдосконалення територіальної організації суспільного розвитку України, підвищення ролі аграрної сфери і сільської місцевості як опори української економіки, основи розвитку малих міських поселень, збереження етнокультурної самобутності української нації. Надбання вченого можуть бути використані на освітянській ниві, при підготовці фахівців 3 питань розвитку i територіальної організації АПК, а також науковцями та управлінцями при здійсненні планування, програмування, при обгрунтуванні стратегій розвитку агропромислового комплексу України та їі регіонів. 


\section{References:}

1. Nagìrna V.P., Rudenko L.G. Sìl's'ka mìscevìst' Ukraïni u kontekstì transformacìjnih procesìv v agrarnìj sferì [The countryside of Ukraine in the context of transformation processes in agrarian sphere] Ukraïns'kij geografičnij žurnal [Ukrainian geographical magazine] 2016, N. 2, pp. 39-47.(In Ukrainian).

2. Palamarčuk M.M. Sveklosaharnoe proizvodstvo Ukrainskoj SSR [Sugar beet production of the Ukrainian SSR]. Kyiv: Naukova dumka, 1964, 215 p. (In Russian).

3. Palamarčuk M.M., Palamarčuk O.M. Ekonomična ì socìal'na geografiâ Ukraïni z osnovami teoriï [Economic and social geography of Ukraine with the basics of the theory]. Kyïv: Znannâ, 1998, 416 p. (In Ukrainian).

4. Palamarčuk M.M., Palamarčuk A.M., Âzynina R.A and others. Territorial'nâ̂ organizaciâ agropromyšlennyh kompleksov [Territorial organization of agro-industrial complexes]. Kyiv: Naukova dumka, 1985, 304 p. (In Russian).

5. Palamarčuk M.M., Âzynina R.A. Specializirovannye agropromyšlennye kompleksy i metodičeskie osnovy ih èkonomiko-geografičeskogo issledovaniâ. [Specialized agro-industrial complexes and methodological foundations of their economic-geographical research]. Geohrafiâ i prirodnye resursy [Geography and natural resources], 1983, № 4, pp. 12-19. (In Russian). 